\title{
粘弾性流体により掃引されるマイクロキャビティ内の慣性弾性不安定
}

鈴木 洋*1, 日出間 るり ${ }^{* 2}$, 菰田 悦之*3

\section{Inertio-elastic flow instability in a micro-cavity swept by a visco-elastic fluid}

\author{
Hiroshi SUZUKI ${ }^{* 1}$, Ruri HIDEMA ${ }^{* 2}$ and Yoshiyuki KOMODA ${ }^{* 3}$ \\ ${ }^{* 1,{ }^{*} 3}$ Department of Chemical Science and Engineering, Kobe University \\ 1-1 Rokkodai-cho, Nada-ku, Kobe 657-8501, Japan \\ ${ }^{* 2}$ Organization of Advanced Science and Technology, Kobe University \\ 1-1 Rokkodai-cho, Nada-ku, Kobe 657-8501, Japan
}

Received 18 November 2014

\begin{abstract}
Inertio-elastic instability characteristics of visco-elastic fluids sweeping a micro-cavity mounted in a micro-duct have been investigated in order to develop a effective micro mixer. The cavity depth, the cavity length and the width of the wider flow path were fixed at 200,1,000 and $400 \mu \mathrm{m}$, respectively while the solvent Reynolds number was changed from 0.100 to 100 . As a visco-elastic fluid, a cationic surfactant/counter-ion system was applied. The molar ratio of counter-ion to surfactant was changed from 1.5 to 10 in order to control rheological characteristics of the fluid. Flow visualization experiments were performed with a high-speed camera mounted on a microscope. From the results, it was that a tonguing motion of the separation fluid bubble tip formed in the downstream region in the cavity occurs at a certain Weissenberg number larger than 200 due to the inertio-elastic instability. The fluctuating bulge structure was also observed on the upstream side wall of the cavity in a higher range of the Weissenberg number. These characteristics were considered to be effective for a mixing process. It was also found that the separation bubble size is determined with Weissenberg number for all fluids treated in this study, but the previous correlation suggested for a macro-scale system does not agree with the present results. This indicated that some different relaxation structure exists in a micro-scale system.
\end{abstract}

Key words : Visco-elastic fluid, Micro-cavity, Inertio-elastic instability, Micro-mxing, Surfactant solution, Visualization

\section{1. 緒言}

化学プロセスにおいてマイクロ流路のような微小な反応器を用いることが注目されており，マイクロリアクタ —（Mae, 2007, Mills, et al., 2007, Pohar and Plazl, 2009, Sallic, et al., 2012）と呼ばれている. マイクロリアクターを 用いるメリットにはいくつかあるが，例えば粒子状物質を作成する場合，粒子径が一様になることが報告されて いる（Lin, et al., 2004, Suzuki, et al., 2008, Breslauer, et al., 2010, Luty-Blocho, et al., 2013）。一方で，マイクロ流路内は 層流であるため, 流体の混合が拡散のみによって行われるため, 反応速度が低下する問題が生じている.

このことに関連して，いくつかのマイクロリアクター用の混合技術が提案されている. 大別して流体に外部か ら仕事を与え, 動的に混合を行うアクティブ混合と, 混合流路を複雑化したり流体の有する非定常性を強化して 静的に混合を促進するパッシブ混合に分かれる(Hessel, et al., 2005). アクティブ混合に関しては, MEMS を利用し た機械的マイクロ攪拌が提案されている(Park, et al., 2008)が, ゲルの熱膨張を利用して, 分岐流路に振動を与える

No.14-00650 [DOI: 10.1299/transjsme.14-00650], J-STAGE Advance Publication date : 16 March, 2015

${ }^{* 1}$ 正員, 神戸大学大学院工学研究科（广 657-8501 兵庫県神戸市灘区六甲台町 1-1)

*2 正員, 神戸大学大学院自然科学系先端融合研究環

${ }^{* 3}$ 神戸大学大学院工学研究科

E-mail of corresponding author: hero@kobe-u.ac.jp 
方法もある(Stoeber, et al., 2007). しかしながら主流はパッシブ混合であり， T 型混合路（Bothe, et al., 2006）や, カオス混合(Mouza, et al., 2008)などの研究があり, マイクロミキサーの比較検討 (Falk and Commenge, 2010, Kashid, et al., 2011）についてもなされている. また Hessel らはアクティブおよびパッシブな混合法について総括してい る. しかしながら, 従来のマイクロミキサーの流路構造が非常に複雑であり, コストや製造方法において不利で あった. また混合によって固体粒子状の物質を生成させる場合, 狭流路内で閉塞が生ずる場合があり, 適応範囲 が限られている．そこで本研究では粘弾性流体が示す慣性弾性不安定性を利用する混合について検討する.

マイクロ流路においては，レイノルズ数は非常に低いが，流体の弾性に関連するワイセンベルグ数は非常に高 い值を示寸このことにより，比較的単純な形状のマイクロ流路内においても慣性弹性不安定性が顕著に表れる (Larson, 1992). Gulati ら (Gulati, et al., 2008)は 90ママイクロベンド内の弾性不安定性 2 次流を利用したマイクロ混 合を提案した．また Rodd ら(Rod, et al., 2005)は急拡大・急縮小部を有するマイクロ流路における慣性弹性不安定 性に関して, 狭流路基準のワイセンベルグ数が 100 程度において慣性弾性不安定性を示すことを明らかにした. 同様の流路で, Hidema ら(Hidema, et al., 2014)は慣性弾性不安定性の臨界值からヒアルロン酸ナトリウムの濃度決 定を行う方法を示した.

Rodd らの用いた流路では狭流路幅が $25 \mu \mathrm{m}$ と非常に狭いものであったが，本研究では固体粒子生成等に供す るよう比較的広い流路幅を有するマイクロダクト片側にキャビティを設けた単純な形状における慣性弹性不安定 性によるマイクロリアクター内の混合特性改善を目的とした実験を行う.キャビティ内では流速が低減するので, 拡大比を適切に選定することによって, 滞留時間を稼ぐことが可能となる. 筆者ら(Suzuki, et al., 2014)はキャビテ イ深さ $20 \mathrm{~mm}$ のマクロ流動に関して検討し, キャビティ内の下流剥離泡上流端が摇動するタンギング運動や, キ ヤビティ内に浸入した流体が一旦キャビティ底面近傍で上流に逆流するバルジ構造の存在を明らかにした。 これ らは慣性弾性不安定性によって生ずる流れであり，マイクロキャビティ内においても，このような慣性弾性由来 の不安定な流れが生ずれば，高効率なマイクロ混合特性が期待されると考えられる.

本研究では比較的広い単純な形状流路で生ずる慣性弾性不安定性を利用したマイクロ混合法の開発を目指した 基礎研究として, 狭流路幅を $200 \mu \mathrm{m}$, キャビティ深さを $200 \mu \mathrm{m}$ およびキャビティ長さを $1,000 \mu \mathrm{m}$ と固定して, 溶液の粘弾性特性を変化させた場合の不安定性流動特性について検討した.

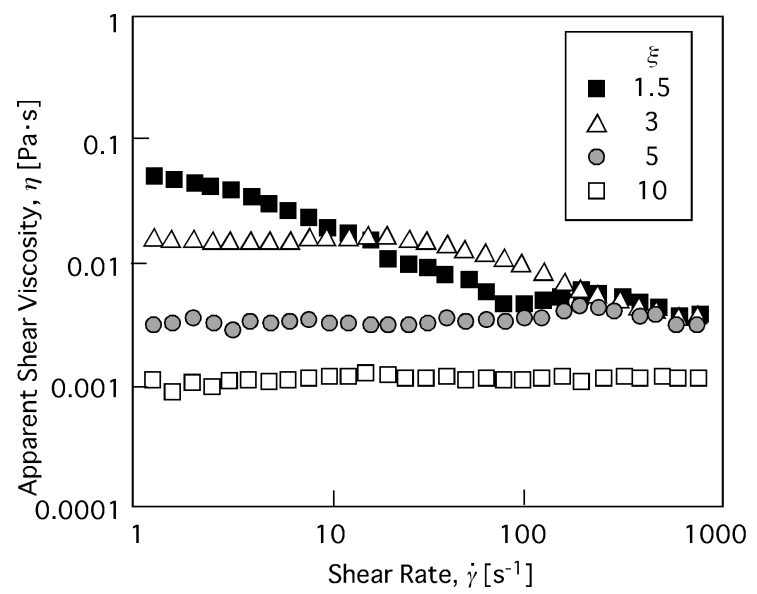

Fig. 1 Apparent shear viscosity of each solution (Suzuki, et al., 2012b).

The solution has shear-thinning tendency when the counter-ion ratio, $\xi[-]$, is low.

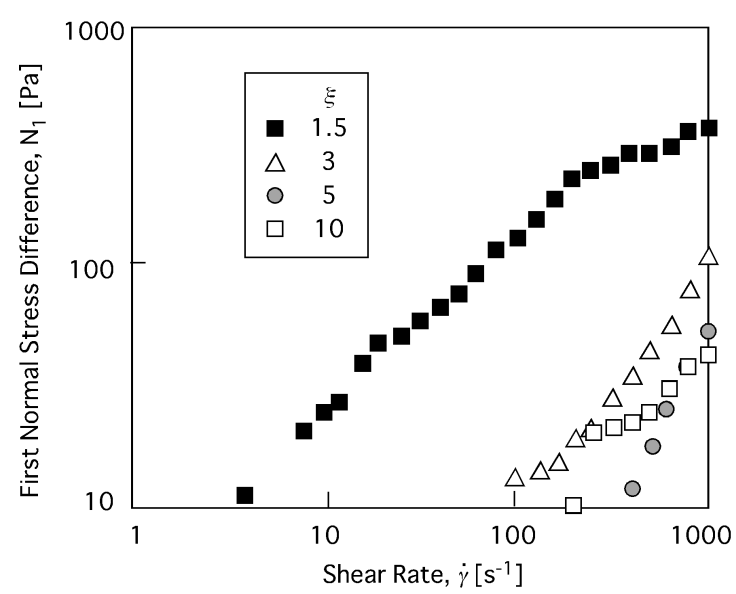

Fig. 2 The first normal stress of each solution (Suzuki, et al., 2012b).

The first normal stress decreases with the counter-ion ratio.

\section{2. 実験方法}

\section{$2 \cdot 1$ 試料}

粘弹性流体にはイオン交換水にカチオン系界面活性剂である塩化オレイルビスヒドロキシエチルメチルアンモ ニム $\left(\mathrm{C}_{18} \mathrm{H}_{35} \mathrm{~N}\left(\mathrm{C}_{2} \mathrm{H}_{4} \mathrm{OH}\right)_{2} \mathrm{CH}_{3} \mathrm{Cl}\right.$ : 商品名 Ethoquad $\left.\mathrm{O} / 12\right)$ を2,000 ppm と対イオン供給剤としてサリチル酸ナトリウム 
を添加したものを用いた。サリチル酸ナトリウムの界面活性剤に対するモル比匝]を $1.5,3,5$ および 10 の 4 段階 に変化させた．このことにより溶液の粘弾性特性を変化させる(Suzuki, et al., 2012a). 溶液は十分に溶解させるた め, 使用する前に少なくとも 24 時間以上常温下においた.

図 1 および 2 に前報(Suzuki, et al., 2012b)で報告したそれぞれの試料の見かけせん断粘度 $\eta[\mathrm{Pa} \cdot \mathrm{s}]$ および第一種法 線応力差 $N_{1}[\mathrm{~Pa}]$ を示す. また図 3 に緩和時間 $t_{\mathrm{r}}$ [s] を示す(Suzuki, et al., 2012b). 見かけせん断粘度は, $\xi=1.5$ の場 合に高いゼロせん断粘度 $\eta_{0}[\mathrm{~Pa} \cdot \mathrm{s}]$ を示し, その後せん断速度 $\dot{\gamma}\left[\mathrm{s}^{-1}\right]$ が上昇するにしたがって粘度が低下するシアシ

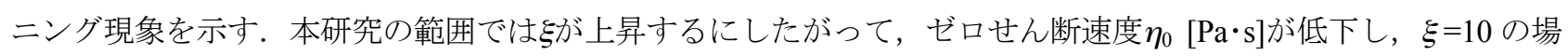
合にはほぼ水と同程度の粘度を示寸. また第一種法線応力差は, $\xi=1.5$ の場合には $\dot{\gamma}>10$ の領域で非常に高い值

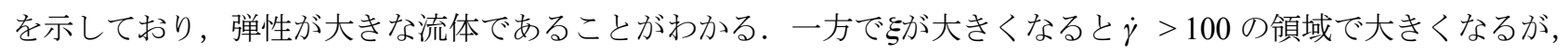
低せん断域では明確な第一種法線応力差を示さない. 本試料の緩和挙動は複雑であり, 前報(Suzuki, et al., 2012b) ではせん断印加を急停止させた際のせん断応力 $\boldsymbol{\tau}[\mathrm{Pa}]$ の緩和挙動を以下の式のように 3 つの緩和挙動の和である とした.

$$
\tau=\tau_{1} e^{-t / t_{11}}+\tau_{2} e^{-t / t_{2} 2}+\tau_{3} e^{-t / t_{3}}
$$

ここで, $t[\mathrm{~s}]$ は時間， $\tau_{1}[\mathrm{~Pa}], \tau_{2}[\mathrm{~Pa}]$ および $\tau_{3}[\mathrm{~Pa}]$ はそれぞれ $t_{\mathrm{r} 1}[\mathrm{~s}], t_{\mathrm{r} 2}[\mathrm{~s}]$ および $t_{\mathrm{r} 3}[\mathrm{~s}]$ の緩和特性を有する構造からの 寄与を表す．緩和時間が長い順に $t_{\mathrm{r} 1}[\mathrm{~s}], t_{\mathrm{r} 2}[\mathrm{~s}]$ および $t_{\mathrm{r} 3}[\mathrm{~s}]$ と定義した. 図 3 にその結果を示す。長い緩和時間は本

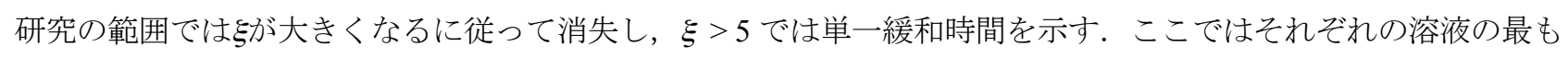
長い緩和時間 $t_{\mathrm{rmax}}[\mathrm{s}]$ を用いて次節で示すワイセンベルグ数を定義した.

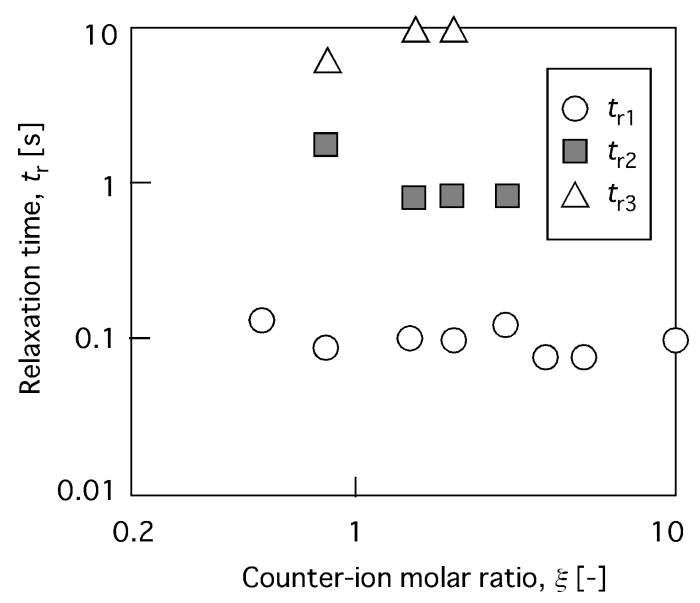

Fig. 3 Effect of the counter-ion ratio on relaxation times of each solution (Suzuki, et al., 2012b). The solution has multi-relaxation times when the counter-ion ratio is low.

\section{$2 \cdot 2$ 試験流路}

図 4 に実験に用いたマイクロ流路を示寸，粘弾性流体はシリンジポンプから所定の流量（設定誤差 1\%以内） で送液され, 内径 $2.0 \mathrm{~mm}$ のテフロン管を通り, テストセクションであるキャビティを有するマイクロ流路に流 入する. テストセクションはポリジメチルシロキサン(PDMS) とガラス板で作成されており, マイクロ流路上流お よび下流には直径 $2 \mathrm{~mm}$, 深さ $200 \mu \mathrm{m}$ のリザーバーを設置し, 上流リザーバー下流端からキャビティ上流端まで, キャビティ下流端から下流リザーバー上流端までの距離をそれぞれ $11 \mathrm{~mm}$ とした. 親水化処理は行っていない. 流体には流れの可視化に供するためにトレーサー粒子として $2.1 \mu \mathrm{m}$ のポリスチレン粒子を溶液に固体体積割合 0.10 vol\%で混入し，顕微鏡に設置したビデオカメラで撮影した．流動の大略を知る実験では，30fps (シャッター 速度 $1 / 8000 \mathrm{~s}$ ) で撮影を行い, 非定常性の詳細を知る実験(表 $1 \xi=1.5, R e=5.00$ の条件)では, $1,000 \mathrm{fps}$ (シャッター 速度 $1 / 10,000 \mathrm{~s}$ )で撮影した. 対物レンズは共通であり, 10 倍率, 開口数 0.25 のものを使用した. キャビティ深さ 
$H[\mathrm{~m}]$, 長さ $L[\mathrm{~m}]$, 広流路幅 $W[\mathrm{~m}]$ および奥行き方向深さをそれぞれ $200 \mu \mathrm{m}, 1,000 \mu \mathrm{m}, 400 \mu \mathrm{m}($ 誤差 $0.5 \%$ 以内)お よび $200 \mu \mathrm{m}$ （誤差 1\%以内）に固定した. いずれの実験においても $30 \mathrm{~s}$ 以上の定常待ちを行ったのち，約 $30 \mathrm{~s} の$ 撮影を行って解析を行った. 水粘度 $\mu[\mathrm{Pa} \cdot \mathrm{s}]$ 基準のレイノルズ数 $R e[-]$, 溶液のゼロせん断粘度基準のレイノルズ

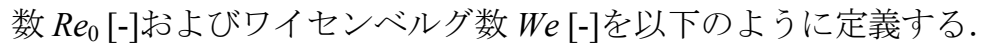

$$
\begin{aligned}
& R e=\frac{\rho U_{\mathrm{m}} H}{\mu} \\
& \operatorname{Re}_{0}=\frac{\rho U_{\mathrm{m}} D_{\mathrm{H}}}{\eta_{0}} \\
& W e=t_{\mathrm{rmax}} \frac{U_{\mathrm{m}}}{(W-H) / 2}
\end{aligned}
$$

ここで $\rho\left[\mathrm{kg} \cdot \mathrm{m}^{-3}\right]$ は溶液の密度であり， $D_{\mathrm{H}}[\mathrm{m}]$ は狭流路の水力相当直径 $(=200 \mu \mathrm{m}), U_{\mathrm{m}}\left[\mathrm{m} \cdot \mathrm{s}^{-1}\right]$ は狭流路における断 面平均速度である。

本研究では各溶液に対してレイノルズ数 $R e$ を 0.100 から 100 まで変化させて実験を行った. その場合の $R e_{0} お$ よび We を表 1 にそれぞれの值をまとめて示す. なお水の場合についても同様の範囲で実験を行った.

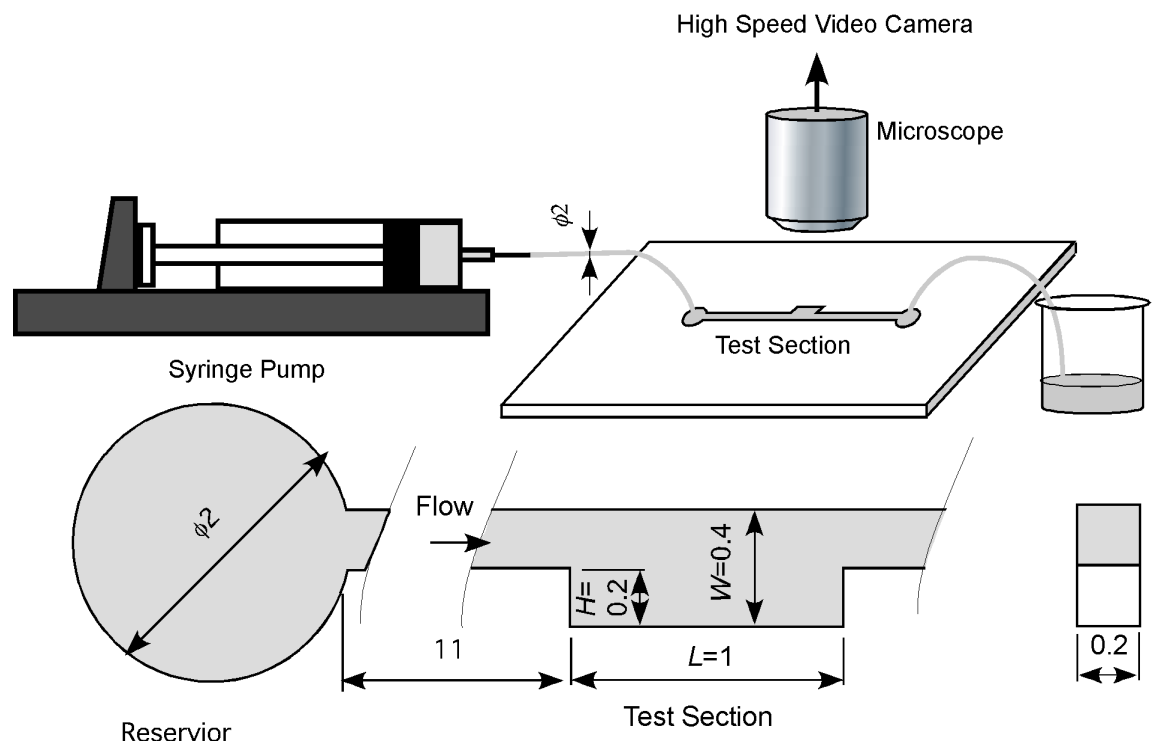

Fig. 4 Experimental apparatus set up and test section. The solution was supplied by a syringe pump to the test section, which has a micro-cavity with the depth of $200 \mu \mathrm{m}$ and the length of $1,000 \mu \mathrm{m}$.

Table 1 Non-dimesional parameters. The Reynolds numbers, $R e$ [-] and $R_{0}[-]$, and the Weissenberg number, We [-], are defined by Eqs. (2) to (4). $\quad \xi[-] \quad$ is the counter-ion ratio to the surfacetants.

\begin{tabular}{c|c|c|c}
\hline$\xi$ & $R e$ & $R e_{0}$ & $W e$ \\
\hline 1.5 & $1.00 \times 10^{-1}$ to 100 & $2.03 \times 10^{-3}$ to 2.03 & 50.4 to $5.04 \times 10^{4}$ \\
\hline 3 & $1.00 \times 10^{-1}$ to 100 & $6.99 \times 10^{-3}$ to 6.99 & 4.27 to $4.27 \times 10^{3}$ \\
\hline 5 & $1.00 \times 10^{-1}$ to 100 & $2.69 \times 10^{-2}$ to 26.9 & $6.28 \times 10^{-1}$ to 628 \\
\hline 10 & $1.00 \times 10^{-1}$ to 100 & $8.87 \times 10^{-2}$ to 88.7 & $6.28 \times 10^{-1}$ to 628 \\
\hline
\end{tabular}

\section{3. 結果および考察}

\section{$3 \cdot 1$ 流動特性}


図 5 に各レイノルズ数における粘弾性流体の流動可視化実験の結果を示す。ここでは粘弾性が最も強く表れる $\xi=1.5$ の場合の結果を示す $(R e=0.100 \sim 50.0)$. また図 5(a)には水の結果を示す $(R e=5.00)$. なお，図にはキャビテ イ上流の上端から剥離した流れの流線を模式的に示した.

図より，水の場合には，キャビティ上流から剥離した流れはキャビティのほぼ中央底部に再付着し，その後壁 面に沿うように流れ, キャビティ下流側面を上昇して, 下流に流出する. 一方, 粘弾性流体の場合でレイノルズ 数が小さい場合 $(R e=0.100)$ には, キャビティ上流側面に沿うように流体がキャビティ内部に浸入し，キャビティ 上流の側面近傍で再付着する.すなわちバラス効果が生ずる．その後キャビティ底面を掃引するように流動する が, キャビティ中間の位置付近で剥離し, 水と比較して大きな剥離泡を形成する. この剥離泡は $R e=5.00$ ではそ の上流端が摇動すなわちタンギング流動を示し, 非定常性が現れる. 剥離泡のサイズは $R e=10.0$ まではレイノル ズ数が大きくなるにしたがって増大するが, $R e=20.0$ では急減する. さらに $R e=50.0$ の場合にはキャビティ上流 上端から剥離した流れが, 上流側面方向に一旦逆流するバルジ構造が現れ, その大きさは非定常に変動し, 再付 着位置の非定常性が現れる.

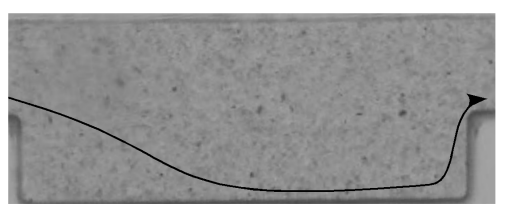

(a) Water at $R e=5.00$

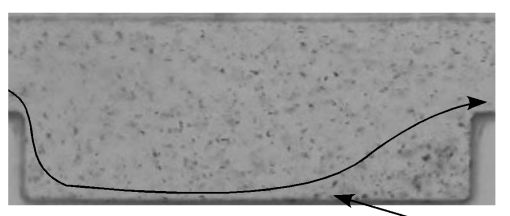

(c) $\xi=1.5$ at $R e=5.00$ Tonguing Motion

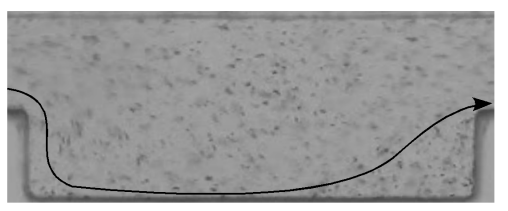

(e) $\xi=1.5$ at $R e=20.0$

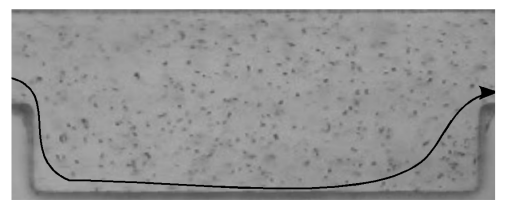

(b) $\xi=1.5$ at $R e=0.100$

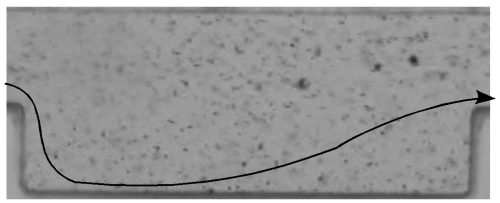

(d) $\xi=1.5$ at $R e=10.0$

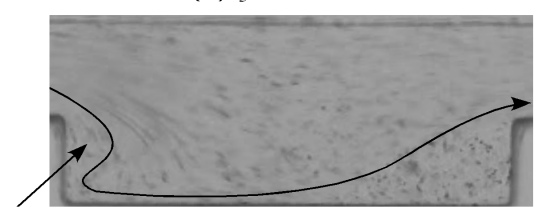

(f) $\xi=1.5$ at $R e=50.0$

Fig. 5 Photos of flows in the micro-cavity. The counter-ion ratio was set at $1.5 \mathrm{in}$ (b) though (f). The solid arrow indicates the schematic flow line separated from the upstream top corner of the cavity.

図 6 にタンギング流動の非定常変化を示す. $\xi=1.5$ の $R e=5.00$ の場合である.また図には剥離泡の境界の形の 変化を模式的に示した。

剥離泡はその中央部近傍が凹み $(t=0.1 \mathrm{~s})$, それによって上流側先端が上流に突出する $(t=0.2 \mathrm{~s})$. その後ふたた び中央部が膨らみ $(t=0.3 \mathrm{~s}$ および $0.4 \mathrm{~s})$, 剥離泡の上流側先端が丸みを帯びつつ収縮する $(t=0.5 \mathrm{~s})$. このような剥 離泡の不安定性は上流側流動の不安定性と関連するものと思われる. 一方で図 7 に示した剥離泡長さ $x_{\mathrm{s}}[\mathrm{m}]$ の時 間変化から, その変動には必ずしも周期性はないことがわかる. また図 6 の結果と併せて考慮すると, 最小緩和 時間より長く, 第 2 緩和時間よりは短い時間スケールで変化している様子がわかる. しかしながら, 高速度撮影 が $5 \mathrm{~s}$ 程度までと限られているため，最長緩和時間の時間スケールについては十分には検証できない。今後，レ イノルズ数の影響を含めて，不安定性の時間スケールについてはより詳細な検討が必要であると思われる.

\section{$3 \cdot 2$ 剥離泡サイズおよび再付着点長さ}

図 8 および 9 にそれぞれ再付着点長さ $x_{\mathrm{r}}[\mathrm{m}]$ および剥離泡長さ $x_{\mathrm{s}}$ をキャビティ深さ $H$ で規格化して示す. 図の エラーバーは各長さの変動幅を示している. また実線で水の場合の結果を示す.また図 8 にはArmaly ら(Armaly, et al., 1983)によって後ろ向きステップ下流で観察された Newton 流体の再付着位置を示す. 
図 8 より, 水の場合の再付着長さはレイノルズ数が上昇するにしたがって増加し, 高レイノルズ数域で測定さ れた Armaly らの結果と一致することがわかる，一方粘弾性が強く表れる $\xi 1.5$ の場合には再付着長さはバラス 効果によって非常に小さい值を示し, バルジ構造が現れる $R e>50$ 以上でやや増加する. $\xi=10$ の場合には水と同

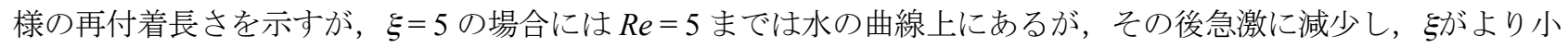
さい場合と同様の值を示す. なお，バルジ構造は $\xi=3$ の場合の $R e=100$ で見られたが， $\xi=1.5$ 以外のその他の場 合には観察されなかった。

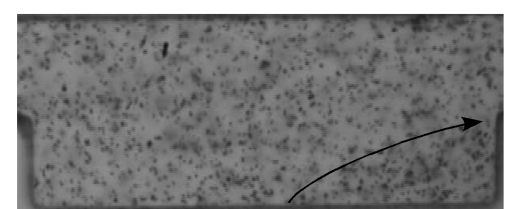

(a) $t=0 \mathrm{~s}$

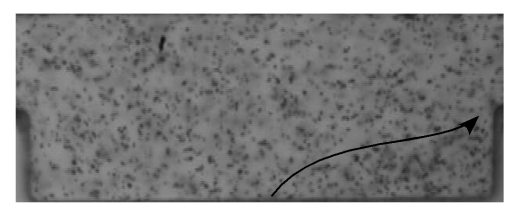

(c) $t=0.2 \mathrm{~s}$

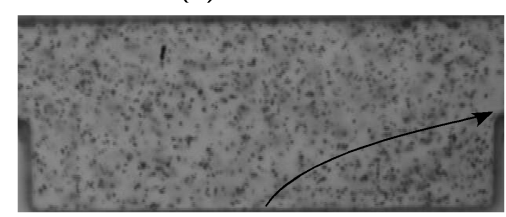

(e) $t=0.4 \mathrm{~s}$

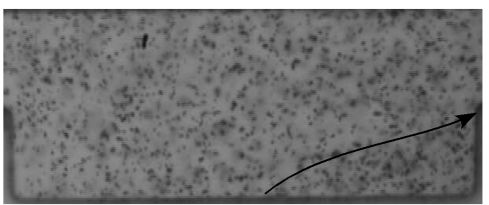

(b) $t=0.1 \mathrm{~s}$

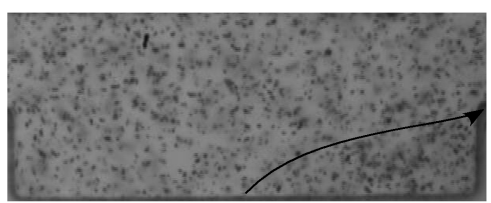

(d) $t=0.3 \mathrm{~s}$

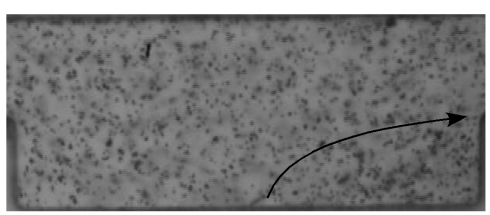

(f) $t=0.5 \mathrm{~s}$

Fig. 6 Time-variation of tonguing motion of the separation bubble $(\xi=1.5, R e=5.00)$. The solid arrows indicate the schematic separation boundary. The tonguing motion occurs relatively slowly.

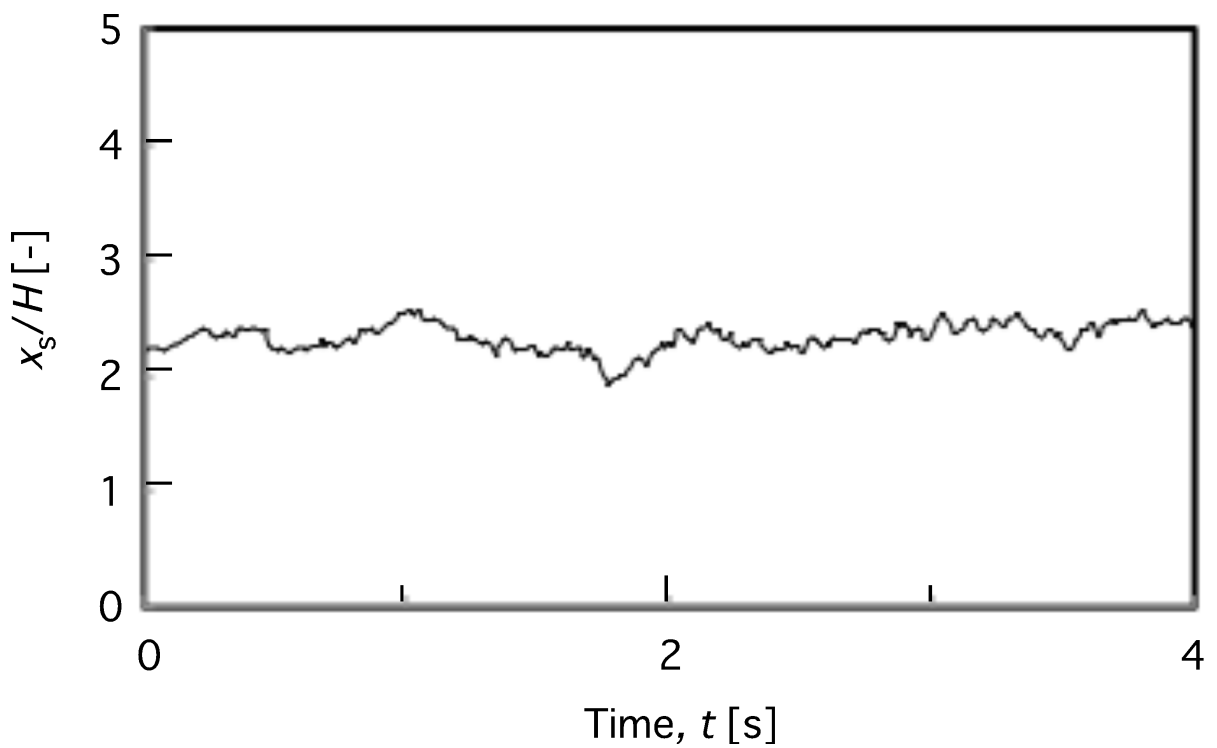

Fig. 7 Time-variation of the separation bubble size $(\xi=1.5)$. The bubble size fluctuates irregularily and the irregularity does not depend on the Reynolds number.

図 9 より，水の剥離泡長さはレイノルズ数が上昇するにしたがって，減少することがわかる. 一方で粘弾性流 体の場合にはあるレイノルズ数において水の值より大きな值を示す.この水の剥離泡長さから乘離して剥離泡長 さが上昇するレイノルズ数は多゙゙きくなるに従って（すなわち粘弾性が弱くなるに従って）上昇する. また一旦 増加した剥離泡長さはあるレイノルズ数でピーク值を示し，その後低下する傾向がある．このピーク值を示すレ 
イノルズ数の值についても方夺きくなるに従って上昇する. また $\xi=1.5$ の場合には $R e=1$ 付近から剥離泡長さの 摇動 (タンギング流動) が開始されるが，タンギング流動が生ずるレイノルズ数もまた㢳増加するに従って上昇 する.これらの現象はワイセンベルグ数の上昇に関連すると考えられる.

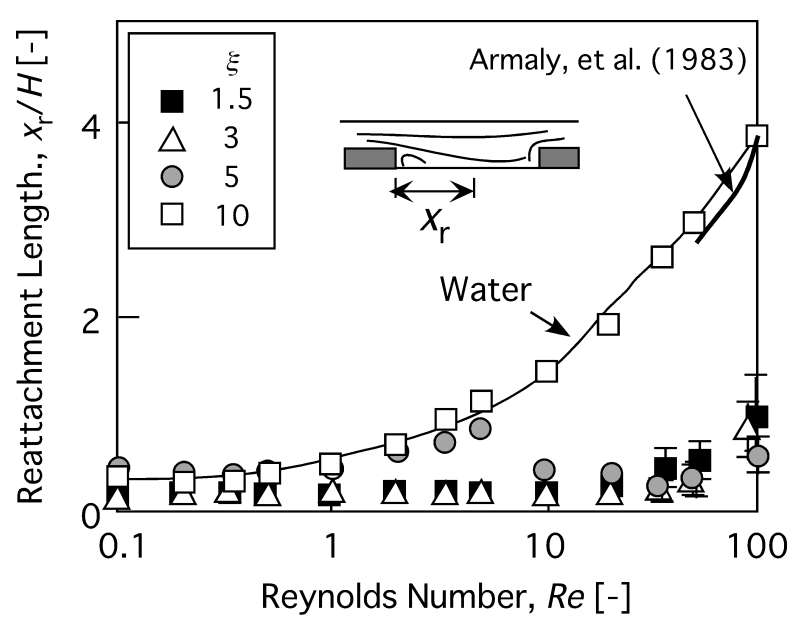

Fig 8 Reattachment points on Reynolds number.

The results in water case agree with that by Armaly et al. (1983). When $\xi$ is low, the reattachment length is small due to Burus effect, but it fluctuates in higher Reynolds number because of the bulge structure appearance.

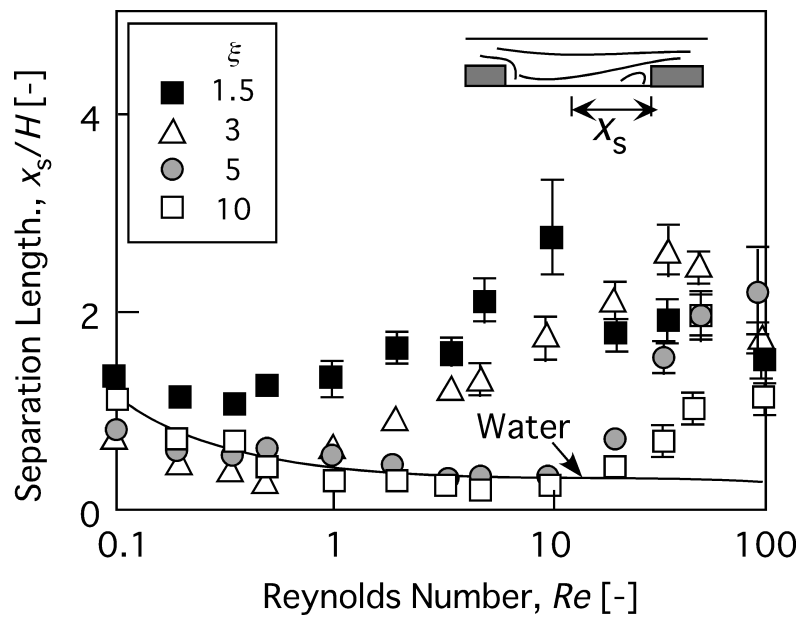

Fig 9 Separation bubble lengths on Reynolds number.

The separation bubble length is large when $\xi$ is low and fluctuates due to the tonguing motion of the separation bubbles.

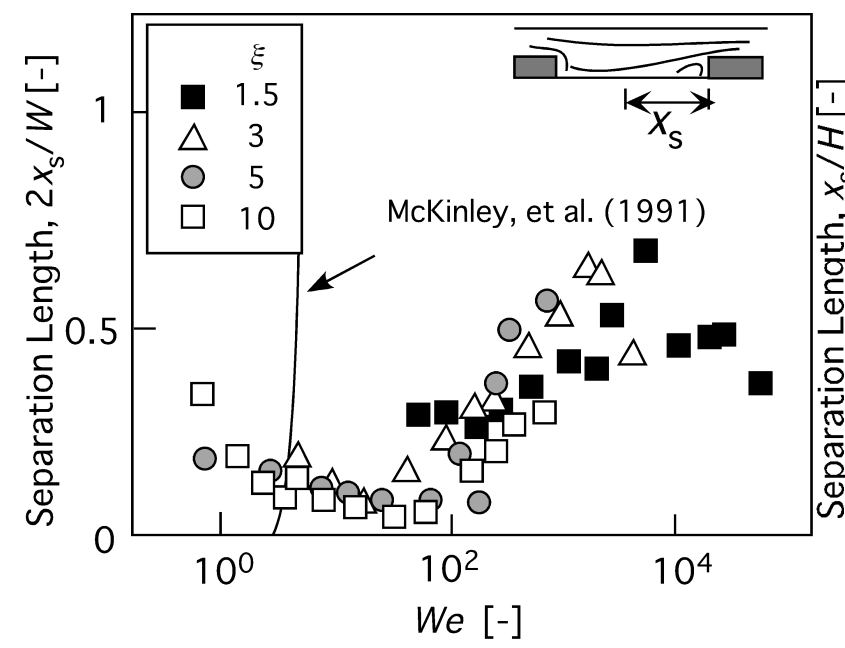

Fig 10 Separation bubble length on Weissenberg number. The solid line indicates the results obtained by McKinley et al. (1991) for a coaxial contraction flow. Sepration bubble sizes are well correlated by Weissenberg number, but the correlateon by McKinley et al. does not work on the present results.

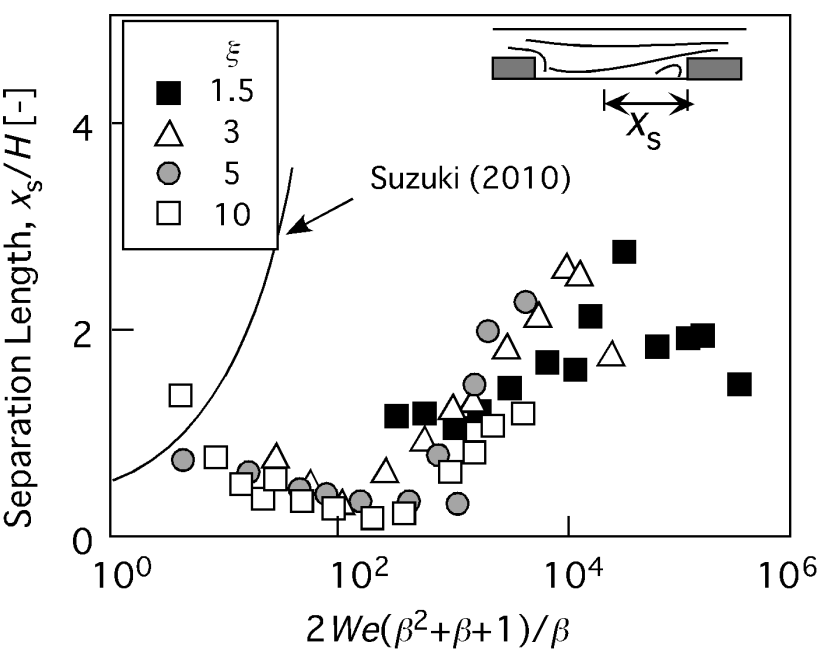

Fig 11 Separation bubble length on Eq. (5).

The solid line indicates the results obtained by Suzuki (2010) for a macro-scale similar flow. Sepration bubble sizes are also well correlated by Eq. (5), but the correlateon by Suzuki neither works on the present results.

図 10 に剥離泡長さをワイセンベルグ数で整理して示す. 図中実線は McKinley ら(McKinley, et al., 1991)が同軸 円筒縮小流に対して調べた，粘弾性流体の結果である. McKinley らの整理にあわせて剥離泡長さを広流路幅の 2 倍で整理した。図より，剥離泡長さは，それぞれの溶液の最大緩和時間で定義したワイセンベルグ数で整理す 
ると，いずれの溶液の結果についても，ほぼ同一の曲線上にあることがわかる．これより粘弾性流体の急縮小流 路における剥離泡長さはワイセンベルグ数で整理できることが明らかとなった．しかしながら一方で, McKinley らの結果とは一致していない.

Suzuki (2010)は粘弾性流体の剥離泡長さは，広流路幅 $W$ を $40 \mathrm{~mm}$ と固定して，Hを 5 20mm に変更した実験 を行い，簡易な解析により以下のような流路拡大比 $\beta=W /(W-H)$ とワイセンベルグ数の関数に比例するとした.

$$
\frac{x_{\mathrm{s}}}{H} \propto \frac{2 W e}{\beta}\left(\beta^{2}+\beta+1\right)
$$

図 11 に本関数に対する剥離泡長さを示す. 図中の実線はSuzuki(2010)の実験結果である. 本研究では拡大比が 2 と一定であるので, 本結果は図 10 で示した結果と同様に, 剥離泡長さがワイセンベルグ数で整理できることを 示しているに過ぎない，一方で，マクロ流路で示した剥離泡長さの結果と一致しておらず，マイクロ流路におけ る剥離泡形成構造は，マクロ流路と本質的に異なる可能性を示唆している.

\section{$3 \cdot 3$ 流動不安定性}

図 12 に流動様式のマップを示寸．横軸はRodd らと同様にゼロせん断粘度基準のレイノルズ数 $R e_{0}[-]$ とした. 実線はタンギング流動が生ずる領域を, 破線はバルジ構造が現れる領域を示す．また Rodd らによって両側急縮 小・急拡大流路内の急縮小部で観察された流動不安定性が生ずる領域を一点破線で示した.

図より, タンギング流動はやや值が大きいものの Rodd らの不安定性と同様にワイセンベルグ数がある值以上 となった場合に生じ，比較的高レイノルズ数では，ほぼ一定のワイセンベルグ数で生ずることがわかる．このこ とから本研究で観察されたタンギング流動不安定性はRodd らが観察した慣性弾性不安定性とほぼ同一の機構に よって生じていると推測される。一方でバルジ構造の現出は, $\xi=3$ 以下での夕観察されており, タンギング流動 のように一定のワイセンベルグ数で観察されていない.このことからバルジ構造の出現および不安定性に関して は同一の機構によって生ずるものではないと思われる. 今後より詳細な検討が必要である.

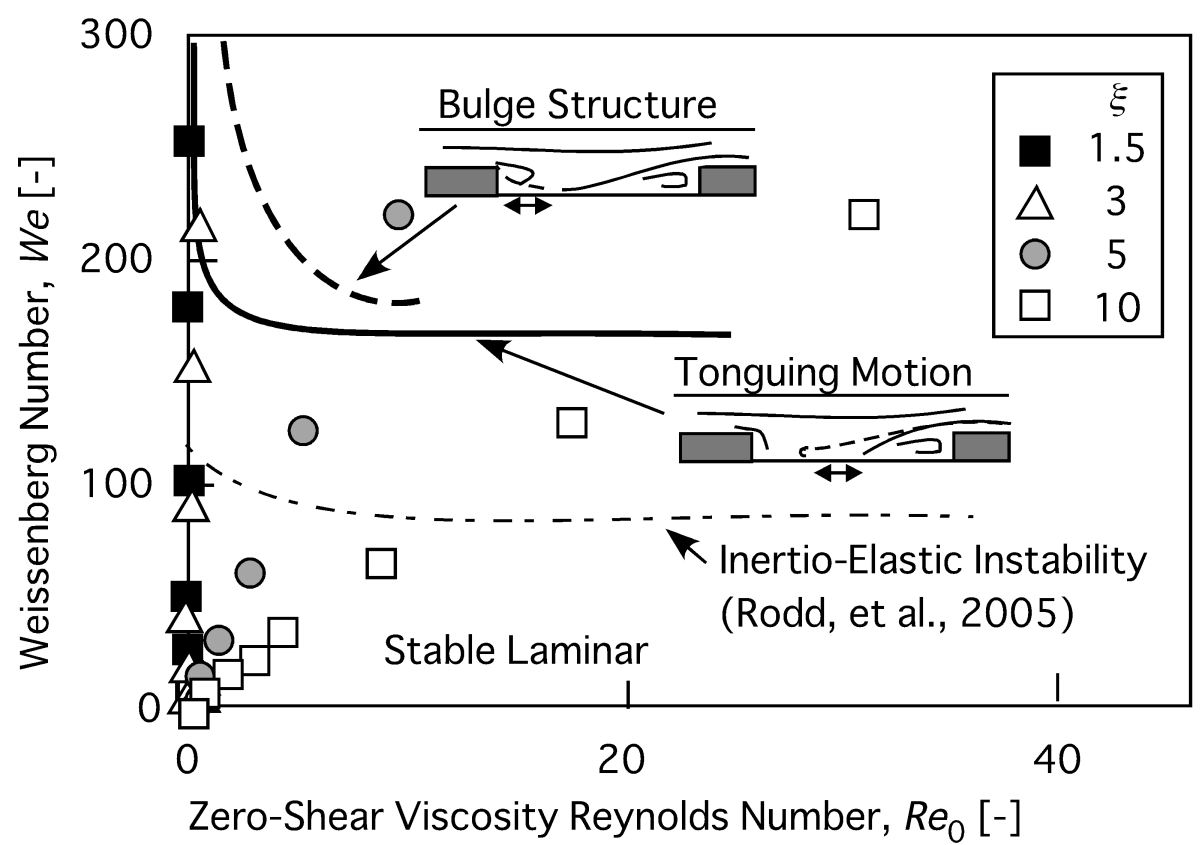

Fig. 12 Flow map on the instability occurrence.

The present tonguing motion appears in a higher Weissenberg number range than that reported by Rodd et al. (2005), but the tendency on Reynolds number is the same as them. However, the bulge structure appearance tendency is not the same as the inertio-elastic instability reported by Rodd et al. 


\section{4. 結言}

本研究ではマイクロキャビティ内で生ずる不安定流動に関して, 流れの可視化実験によって検討した. キャビ ティ深さ, キャビティ長さ, 広流路幅およびスパン方向厚さをそれぞれ $200 \mu \mathrm{m}, 1000 \mu \mathrm{m}, 400 \mu \mathrm{m}$ および $200 \mu \mathrm{m}$ と固定し, 水粘度基準のレイノルズ数 Re を $1.00 \times 10^{-1} \sim 100$ まで変更して実験を行った. また試料としてカチオン 系界面活性剂／対イオンの混合溶液を用い, 界面活性剂濃度を固定して対イオンの界面活性剂に対するモル比 $\xi$ を変更することによって粘弹性特性の異なる 4 種の溶液に関する実験を行った。 その結果, 以下のような結論を 得た.

1） 粘弾性が強い $\xi=1.5$ の場合には, $R e>1$ でキャビティ下流部に形成される剥離泡上流端が摇動するタン ギング流動が観察された. また $R e>50$ でキャビティ上流上方端からの剥離流が上流側壁に再接近するバルジ 構造が観察された.

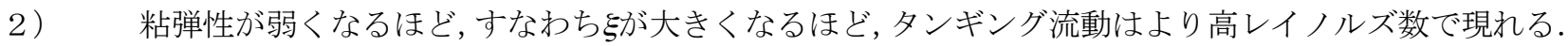

3）再付着長さは粘弾性を強く示寸場合, バラス効果によって非常に小さい值を示すが, バルジ構造の現出 によって若干増加する.

4）剥離泡長さはあるレイノルズ数で水の值より大きくなるが, あるレイノルズ数で一旦ピークをとったあ と, その後減少する.この剥離泡長さが上昇するレイノルズ数は多大゙きくなるに従って増加する.

5）剥離泡長さは，それぞれの溶液の最大緩和時間で定義したワイセンベルグ数によって整理されるが，ミ リオーダーで行った実験の結果とは一致しない.

6 ）＜wide>バルジ構造はタンギング流動の不安定性出現と関連せず，別の機構によって生ずる.

\section{References}

Armaly, B. F., Durst, F., Pereira, J. C. F. and Schönung, B., Experimental and theoretical investigation of backward-facing step flow, Journal of Fluid Mechanics, Vol. 127 (1983), pp. 473-496.

Bothe, D., Stemich, C. and Warnecke, H.-J., Fluid mixing in a T-shaped micro-mixer, Chemical Engineering Science, Vol. 61 (2006), pp.2950-2958.

Breslauer, D. N., Muller, S. J. and Lee, L. P., Generation of monodisperse silk microspheres prepared with microfluidics, Biomocromolecules, Vol. 11 (2010), pp.643-647.

Falk, L. and Commenge, J.-M., Performance comparison of micromixers, Chemical Engineering Science, Vol. 65 (2010), pp. 405-411.

Gulati, S., Dutcher, C. S., Liepmann, D. and Muller, S. J., Elastic secondary flows of semidilute DNA solutions in abrupt $90^{\circ}$ microbends, Physical Review E, Vol. 78 (2008), \#036314.

Hessel, V., Löwe, H. and Schönfeld F., Micromixers: A review on passive and active mixing principles, Chemical Engineering Science, Vol. 60 (2005), pp.2479-2501.

Hidema, R., Suzuki, H. and Komoda, Y., Elastic instability of hyaluronate solution in micro abrupt contraction-expansion Channels, Proceedings of AIChE Annual Meeting (2014), \#381883, Atlanta.

Kashid, M., Renken, A. and Kiwi-Minsker, L., Mixing efficiency and energy consumption for five generic microchannel designs, Chemical Engineering Journal, Vol. 167 (2011), pp.436-443.

Larson, R.G., Instabilities in viscoelastic flows, Rheologica Acta, Vol. 31 (1992), pp.213-263.

Lin, X. Z., Terepka, A. D. and Yang, H., Synthesis of silver nanoparticles in a continuous flow tabular microreactor, Nano Letters, Vol. 4, No. 11 (2004), pp. 2227-2232.

Luty-Blocho, M., Wojnicki, M., Paclawski, K. and Fitzner, K., The synthesis of platinum nanoparticles and their deposition on the active carbon fibers in one microreactor cycle, Chemical Engineering Journal, Vol. 226 (2013), pp. 46-51.

McKinley, G. H., Raiford, W. P., Brown, R. A. and Armstrong, R. C., Nonlinear dynamics of viscoelastic flow in axisymmetric abrupt contractions, Journal of Fluid Dynamics, Vol. 223 (1991), pp. 411-456.

Mae, K., Advanced chemical processing using microspace, Chemical Engineering Science, Vol. 62 (2007), pp. 4842-4851.

Mills, P. L., Quiram, D. J. and Ryley, J. F., Microreactor technology and process miniaturization for catalytic reactions-A perspective on recent developments and emerging technologies, Chemical Engineering Science, Vol. 62 (2007), pp. 6992-7010.

Mouza, A.A., Patsa, C.-M. and Schönfeld, F., Mixing performance of a chaotic micro-mixer, Chemical Engineering Research 
and Design, Vol. 86 (2008), pp.1128-1134.

Park, J.-Y., Kim, Y.-D., Kim, S.-R., Han, S.-Y. and Maeng, J.-S., Robust design of an active micro-mixer based on the Taguchi method, Sensors and Activators B, Vol. 129 (2008), pp.790-798.

Pohar, A. and Plazl, I., Process intensification through microreactor application, Chemical and Biochemical Engineering Quarterly, Vol. 23, No. 4 (2009), pp.537-544.

Rodd, L. E., Scott, T. P., Boger, D. V., Cooper-White, J. J. and McKinley, G. H., The inertio-elastic planar entry flow of low-viscosity elastic fluids in micro-fabricated geometries, Journal of Non-Newtonian Fluid Mechanics. Vol. 129 (2005), pp. 1-22.

Sallic, A.,Tusek, A. and Zelic, B., Application of microreactors in medicine and biomedicine, Journal of Applied Biomedicine, Vol. 10 (2012), pp. 137-153.

Stoeber, B., Liepmann, D. and Muller, S. J., Strategy for active mixing in microdevices, Physical Review E, Vol. 75 (2007), \#066341.

Suzuki, H., Separation characteristics of visco-elastic fluid in a cavity, Journal of Chemical Engineering of Japan, Vol. 43, No. 5 (2010), pp. 421-428.

Suzuki, H., Hamamura, J., Katsuda, T., Komoda, Y., Katoh, S. and Usui, H., Size characteristics of liposomes formed in a micro-tube, Journal of Chemical Engineering of Japan, Vol. 41, No. 8 (2008), pp. 739-743.

Suzuki, H., Higuchi, Y., Komoda, Y. and Hidema, R., Effect of the molar ratio of counter-ions on flow characteristics of surfactant solutions sweeping cavities, Proceedings of the $23^{\text {rd }}$ International Symposium on Transport Phenomena (2012a) \#156, Auckland.

Suzuki, H., Higuchi, Y., Watanabe, H., Komoda, Y., Ozawa, S., Nishimura, T. and Takenaka, N., Relaxation behavior of a drag-reducing cationic surfactant solution, Nihon Reoroji Gakkaishi, Vol. 40, No. 2 (2012b), pp. 85-90.

Suzuki, H., Sato, H., Hidema, R. and Komoda, Y., Bulge structure in a cavity swept by a viscoelastic fluid, Journal of Physics: Conference Series, Vol. 530 (2014), \# 012055. 